\title{
Dünyada ve Türkiye’de Yemeklik Dane Baklagillerin Durumu
}

\author{
Ali Gülümser \\ Emekli Öğretim Üyesi \\ Sorumlu yazar e-posta (Corresponding author e-mail): gulumser@omu.edu.tr
}

\section{Öz}

Kutup bölgeleri hariç baklagiller familyasına giren bütün bitkiler dünyanın her yerinde yetişmekte olan tek yıllık ve çok yıllık 12.000 türü kapsamaktadır. Bunlardan sadece 200 türün ziraati yapılmaktadır. Bu türlerin içerisinde yemeklik olarak kullanılanlar fasulye (Phaseolus vulgaris L.), nohut (Cicer arietinum L.), mercimek (Lens culunaris Medik. , Lens esculenta Moench.), bakla (Vicia faba L ), börülce (Vigna sinensis L.) ve bezelye (Pisum sativum L. )'dir. Yemeklik tane baklagiller binlerce yıldır insan beslenmesinde bitkisel proteinin ana kaynağı olarak dünya ve ülkemizde çok önemli bir yer tutmuştur. Dünya ve Türkiye'de tarla bitkileri üretimi yapılan alanlarda ilk sırayı tahıllar sahip olurken bunu yemeklik baklagiller izlemektedir. Dünyada yaklaşık 1.5 milyar hektar olan tarım alanlarının, 66.8 milyon hektarında yemeklik baklagil ekilmekte ve 61.2 milyon ton üretim yapılmaktadır. Dünyada en fazla ekilen yemeklik baklagiller sırasıyla fasulye, nohut, börülce, bezelye mercimek ve bakla olurken, en fazla üretilenler ise fasulye, nohut, bezelye, börülce, mercimek ve bakla olmuştur. Ülkemizde toplam 24.3 milyon hektar olan tarım alanının, 735 bin hektarında yemeklik baklagil ekilmekte, yaklaşık 1 milyon ton üretim yapılmaktadır. Ülkemizde en fazla ekilen yemeklik baklagiller sırasıyla nohut (388 bin ha), mercimek (323 bin ha), fasulye (91 bin ha), bakla (3.2 bin ha), börülce (1.9 bin ha) ve bezelye ( 1.1 bin ha) olurken, en fazla üretilenler ise nohut (411 bin ton), mercimek (540 bin ton), fasulye (215 bin ton), bakla ( 7 bin ton), bezelye (2.9 bin ton) ve börülce (2.4 bin ton) olmuştur.

Anahtar Kelimeler: Yemeklik tane baklagil, nohut protein

\section{Situation of Pulse in Turkey and World}

\begin{abstract}
Leguminosae family include annual or perennial 12.000 species which can be grown in all the world except arctic regions. Only 200 speceis are cultivated. The cultivated legumes speceis as pulse are bean (Phaseolus vulgaris L.), chickpea (Cicer arietinum L.), lentil (Lens culunaris Medik. , Lens esculenta Moench.), fababean (Vicia faba L ), cowpea (Vigna sinensis L.) and pea (Pisum sativum L. ). Pulses have held an importand place in human diet as the main source of vegetable protein in Turkey and world for thousand years. After cereals, pulses are the second crop having the highest cultivation area. In the total field crops area of the world, which is approximately 1.5 million hectares, pulses are planted on 66.8 million hectares with 61.2 million tons production. The most cultivated pulses in the world are bean, chickpea, cowpea, pea, cowpea and faba bean while the most produced are bean, chickpea, pea, cowpea, lentil and faba bean respectively. In the total 24.3 million hectares field crop areas of Turkey, pulses grown on 735 thousand hectares with 1 million tones production. In Turkey, the most seeded pulses are chickpea (388 thousand hectares), lentil (323 thousand hectares), bean (91 thousand hectares), faba bean (3.2 thousand hectares), cowpea (1.9 thousand hectares) and pea (1.1 thousand hectares) while the most produced are chickpea (411 thousand tons), lentil (540 thousand tons), bean ( 215 thousand tons), faba bean (7 thousand tons), pea (2.9 thousand tons) and cowpea (2.4 thousand tons).
\end{abstract}

Keywords: Pulse, chickpea, protein

\section{Giriş}

$\mathrm{B}$ aklagiller familyasına giren bitkilerin tümü kutup bölgeleri hariç dünyanın diğer bütün iklim şartlarında yetişmekte olan tek yıllık ve çok yıllık olmak üzere 12.000 türü kapsamakta ve bunlardan sadece 200 türün tarımı yapılmaktadır. Bu türlerin içerisinde yemeklik

tane baklagil olarak kullanılanlar fasulye (Phaseolus vulgaris L.), nohut (Cicer arietinum L.), mercimek (Lens culunaris Medik. , Lens esculenta Moench.), bakla (Vicia faba L. ), börülce (Vigna sinensis L.) ve bezelye (Pisum sativum L. )'dir (Akçin 1988). Yemeklik tane 
baklagiller binlerce yıldır insan beslenmesinde bitkisel proteinin ana kaynağı olarak dünya ve ülkemizde çok önemli bir yer tutmuştur (Akova 2009). Kültürü yapılan yemeklik baklagillerin hepsi tek yıllıktır. Mercimek ve baklanın diğer türlere oranla düşük sıcaklığa dayanıklı olmaları nedeni ile kışlık olarak ta yetiştirilebilmelerinin yanında, hepsi yazlık bitkilerdir. Sıcaklık isteği en fazla olan fasulye ve börülce olurken, bunu sırasıyla nohut, bezelye, bakla ve mercimek izler. Kültürü yapılan bu türler içerisinde fasulye, börülce, bakla ve bezelye su isteği fazla olan türler iken, mercimek ve nohut ise genelde kurak alan bitkileridir. Toprak isteği bakımından ne ağır ne de fazla hafif toprakları istemeyen yemeklik baklagiller tınlı- humuslu ve kireççe zengin, $\mathrm{pH}$ 6-8 arsında, azot ve fosforca zengin toprakları isterler (Akçin 1988; Kün ve ark. 2005).

Dünya ve Türkiye'de tarla bitkileri üretimi yapılan alanlarda ilk sırayı tahıllar sahip olurken bunu yemeklik baklagiller izlemektedir. Dünyada yaklaşık 1.5 milyar hektar olan tarım alanlarının, 66.8 milyon hektarında yemeklik baklagil ekilmekte ve 61.2 milyon ton üretim yapılmaktadır. Dünyada en fazla ekilen yemeklik baklagiller sırasıyla fasulye, nohut, börülce, bezelye, mercimek ve bakla olurken, en fazla üretilenler ise fasulye, nohut, bezelye, börülce, mercimek ve bakla olmuştur. Ülkemizde toplam 24.3 milyon hektar olan tarım alanının, 735 bin hektarında yemeklik baklagil ekilmekte, yaklaşık 1 milyon ton üretim yapılmaktadır. Ülkemizde en fazla ekilen yemeklik baklagiller sırasıyla nohut, mercimek, fasulye, bakla, börülce ve bezelye olurken, en fazla üretilenler ise nohut, mercimek, fasulye, bakla, bezelye ve börülce olmuştur (Anonim 2014).

Yemeklik baklagiller dünyadaki 2 milyar'dan fazla insan için protein kaynağıdır. Yağ oranı düşük, karbonhidrat oranı yüksek ve besleyicidir. Dünyada insan beslenmesindeki bitkisel proteinlerin \%22'si, karbonhidratların \%7'si; hayvan beslenmesindeki proteinlerin \%38'i karbonhidratların $\% 5$ 'i yemeklik tane baklagillerden sağlanmaktadır. Türkiye, baklagillerin gen merkezi olarak kabul edilen 'verimli hilal'in en önemli parçasıdır. Bunun dışında tüketim oranları açısından dünyada önemli bir yeri olduğu gibi tarihsel olarak net ihracatçı konumunda olmuştur. Ülkemizin hemen hemen her bölgesinde yetiştirilen yemeklik tane baklagiller Türk mutfağının ve özellikle dar gelirli ailelerin protein kaynağını oluşturmaktadır. Ürettiğimiz baklagillerin önemli bir kısmı yurt içinde tüketilmektedir. Ülkemizde kişi basına yıllık ortalama 3-4 kg fasulye, $4-5 \mathrm{~kg}$ mercimek ve 5-6 kg nohut tüketildiği dikkate alındığında, yemeklik tane baklagillerin ülkemiz insanları açısından önemi büyüktür (Adak ve ark. 2010).

Besin değerleri bakımından zengin oldukları gibi yetiştirildikleri toprağa da olumlu etkilerde bulunmaktadır. Havanın serbest azotunu toprağa bağlama özelliklerinden dolayı hem çevre açısından hem de sürdürülebilirliğin açısından bu bitkilerin önemleri artmaktadır. Baklagiller ile ortak yasayan Rhizobium türü bakteriler, havada serbest halde bulunan azotu yasadıkları ortama bağlayarak toprağı organik azotça zenginleştirirler ve gereksinimlerini bu azottan sağlarlar. Yemeklik baklagillerin toprağa bağladıkları azot miktarı çeşide ve çevre koşullarına göre, yılda $5-20 \mathrm{~kg} / \mathrm{da}$ arasında değişmektedir (Şehirali 1988).

\section{Üretimi \\ Dünya ve Türkiye'de Yemeklik Baklagil}

\section{Dünyada Yemeklik Baklagil Üretimi}

2013 yılı verilerine göre dünya toplam baklagil ekim alanı 66.8 milyon ha üretimi ise 61.3 milyon ton dolaylarındadır. En fazla ekim alanı (29.234.228 ha) ve üretim miktarına (23.139.004 ton) fasulye sahipken, en yüksek verim seviyesi $(1.651 \mathrm{~kg} / \mathrm{ha})$ bakladadır. Dünyada ekim alanı bakımından fasulye ilk sırayı alırken bunu nohut, börülce, bezelye, mercimek ve bakla takip etmekte, üretimde ise bezelye börülcenin önüne geçmektedir (Çizelge 1).

Çizelge 1. 2013 Yılı dünyada yemeklik tane baklagiller ekim alanı, üretim ve verimi

Table 1. Global cultivation area, production and yield of grain legumes in 2013

\begin{tabular}{llll}
\hline Cinsler & Ekim Alanı (ha) & Üretim (ton) & Verim (kg/ha) \\
\hline Fasulye & 29234228 & 23139004 & 791 \\
Nohut & 13540398 & 13102023 & 967 \\
Bezelye & 6379535 & 10979946 & 1139 \\
Börülce & 11316105 & 5718145 & 505 \\
Mercimek & 4344671 & 4951720 & 1140 \\
Bakla & 2057883 & 3398330 & 1651 \\
Toplam & 66872820 & 61289168 & ------ \\
\hline
\end{tabular}

(Kaynak: FAO, 2015), (Source: FAO, 2015) 
Çizelge 2. Yıllar itibariyle dünyada yemeklik tane baklagiller ekim alanı, üretim ve verimi Table 2. Long term global cultivation area, production and yield of grain legumes

\begin{tabular}{llll}
\hline Yıllar & Ekim Alanı (ha) & Üretim (ton) & Verim (kg/ha) \\
\hline 1961 & 8597758 & 32822788 & 649 \\
1970 & 53485094 & 35739884 & 695 \\
1980 & 51522326 & 34864946 & 749 \\
1990 & 56817927 & 50032136 & 1001 \\
2000 & 53974161 & 46737594 & 1017 \\
2010 & 67833563 & 61078304 & 1106 \\
2011 & 67189630 & 58443661 & 1088 \\
2012 & 66488273 & 60800696 & 1105 \\
2013 & 66872820 & 61289168 & 1129 \\
\hline
\end{tabular}

(Kaynak: FAO, 2013), (Source: FAO, 2013)

Çizelge 3. 2013 Yılı ülkeler itibariyle fasulye, mercimek, nohut, börülce, bakla ve bezelye ekim alanı, üretim ve verim değerleri

Table 3. Bean, lentil, chickpea, cowpea, fababean and pea cultivation area, production and yield by countries in 2013

\begin{tabular}{lllll}
\hline & Ülkeler & Ekim Alanı (Ha) & Üretim (ton) & Verim (kg/da) \\
\hline \multirow{2}{*}{ Fasulye } & Hindistan & 9100000 & 3630000 & 398 \\
& Brezilya & 2831008 & 2936444 & 1037 \\
& Myammar & 2700000 & 3800000 & 1407 \\
\hline \multirow{2}{*}{ Mercimek } & Hindistan & 1890000 & 1134000 & 600 \\
& Kanada & 954200 & 1880500 & 1970 \\
& Türkiye & 281178 & 417000 & 1483 \\
\hline \multirow{2}{*}{ Nohut } & Hindistan & 9600000 & 8832500 & 920 \\
& Pakistan & 992000 & 751000 & 757 \\
& Avustralya & 573600 & 813300 & 1417 \\
\hline \multirow{2}{*}{ Börülce } & Nijer & 4700000 & 1300000 & 276 \\
& Nijeriya & 3200000 & 2500000 & 781 \\
& Burkina Faso & 1200500 & 580000 & 483 \\
\hline \multirow{2}{*}{ Bakla } & Çin & 922000 & 1400000 & 1518 \\
& Morokko & 205520 & 156669 & 762 \\
& Etiopya & 151225 & 149374 & 987 \\
\hline \multirow{2}{*}{ Bezelye } & Kanada & 1311100 & 3849300 & 2935 \\
& Rusya & 965952 & 1380000 & 1397 \\
& Çin & 905000 & 1350167 & 1524 \\
\hline
\end{tabular}

(Kaynak: FAO, 2013) (Source: FAO, 2013)

Yıllar itibariyle dünyada yemeklik baklagil ekim alanı, üretim ve verim değerlerinde artış gerçekleşmiştir. Ekim alanı ve üretimde 1990 yılından 2000 yılına kadar belirgin bir düşüş olmuş fakat 2000 yılından itibaren azalarak artış olmuştur (Çizelge 2).

Dünyada en fazla baklagil üreten ülke Hindistan'dır. Ülkeler itibariyle en fazla fasulye, nohut, mercimek ekilen ülke Hindistan olurken, en fazla börülce Nijerya'da, bakla Çin'de, bezelye'de Kanada'da ekilmektedir (Çizelge 3).

Yemeklik baklagiller dünyanın her yerinde yetiştirilmekler birlikte, genel olarak belirli cinslerin üretimi kıtalara göre ön plana çıkmaktadırlar. Dünyada en fazla ekim alanına sahip fasulye üretimi Asya ve Afrika, nohut üretimi ise Asya ve Afrika, bezelye üretimi Amerika, Asya ve Avusturya, börülce üretimi Afrika ve Asya ülkelerinde, mercimek üretimi Amerika ve Asya, bakla üretimi ise Asya ve Afrika kıtalarında yoğunluk kazanmıştır (Çizelge 4).

Gelişmekte olan ülkelerin yanında, son yıllarda gelişmiş ülkelerde de baklagillere olan talep artış göstermiştir. Ancak, biyoyakıt üretimi için gerekli olan hammadde temini amacıyla üretimi gerçekleştirilen mısır ve şeker kamışı gibi ürünlere kayma nedeniyle baklagil ekim alanları azalma göstermiştir (Akova 2009; Şehirali ve ark. 2005). 
Çizelge 4. Kıtalarda yemeklik tane baklagil ekim alanı, üretim ve verim değerleri Table 4. Cultivation area, production and yield of grain legumes by continents

\begin{tabular}{|c|c|c|c|c|}
\hline Kitalar & Cinsler & Ekim Alanı (Ha) & Üretim (Ton) & Verim $(\mathrm{Kg} / \mathrm{Ha})$ \\
\hline \multirow{6}{*}{ Afrika } & Fasulye & 7694513 & 4860480 & 631 \\
\hline & Bakla & 570465 & 737733 & 1293 \\
\hline & Nohut & 483485 & 530952 & 1098 \\
\hline & Börülce & 11075159 & 5421561 & 489 \\
\hline & Mercimek & 178159 & 185925 & 1043 \\
\hline & Bezelye & 811815 & 719546 & 886 \\
\hline \multirow{6}{*}{ Amerika } & Fasulye & 6977288 & 7089875 & 1016 \\
\hline & Bakla & 173367 & 205336 & 1184 \\
\hline & Nohut & 329735 & 596248 & 1808 \\
\hline & Börülce & 73799 & 79276 & 1074 \\
\hline & Mercimek & 1116767 & 2122106 & 1900 \\
\hline & Bezelye & 1787712 & 4748067 & 2655 \\
\hline \multirow{6}{*}{ Asya } & Fasulye & 14237089 & 10635154 & 747 \\
\hline & Bakla & 963589 & 1494411 & 1550 \\
\hline & Nohut & 12079222 & 11067997 & 916 \\
\hline & Börülce & 160402 & 193272 & 1204 \\
\hline & Mercimek & 2819784 & 2245790 & 796 \\
\hline & Bezelye & 1875177 & 2229016 & 1188 \\
\hline \multirow{6}{*}{ Avrupa } & Fasulye & 260088 & 500495 & 1924 \\
\hline & Bakla & 238462 & 663350 & 2781 \\
\hline & Nohut & 74356 & 93526 & 1257 \\
\hline & Börülce & 6745 & 24036 & 3563 \\
\hline & Mercimek & 83861 & 70599 & 841 \\
\hline & Bezelye & 1723501 & 3020567 & 1752 \\
\hline \multirow{6}{*}{ Okyanusya } & Fasulye & 65250 & 53000 & 812 \\
\hline & Bakla & 112000 & 297500 & 2656 \\
\hline & Nohut & 573600 & 813300 & 1417 \\
\hline & Börülce & - & - & - \\
\hline & Mercimek & 146100 & 327300 & 2240 \\
\hline & Bezelye & 181330 & 262750 & 1449 \\
\hline
\end{tabular}

(Kaynak: FAO, 2013) (Source: FAO, 2013)

Çizelge 5. 2014 yılı Türkiye'de yemeklik tane baklagiller ekim alanı, üretim ve verimi Table 5. Cultivation area, production and yield of grain legumes in Turkey (2014)

\begin{tabular}{llll}
\hline \multicolumn{1}{c}{ Cinsler } & Ekim Alanı (bin ha) & Üretim (bin ton) & Verim (kg/da) \\
\hline Fasulye & 91 & 215 & 238 \\
Nohut & 388 & 411 & 116 \\
Bezelye & 1.1 & 2.9 & 260 \\
Börülce & 1.9 & 2.4 & 103 \\
Mercimek & 323 & 540 & 131 \\
Bakla & 3.2 & 7.0 & 216 \\
\hline
\end{tabular}

(Kaynak: TÜIK 2014 ), (Source: TÜIK, 2014)

\section{Türkiye'de Yemeklik Baklagil Üretimi}

2015 yılı verilerine göre ülkemizde her yıl işlenen tarım alanlarının yaklaşık \% 3.2'lik bölümünde baklagiller yetiştirilmektedir. Ekiliş alanı bakımından baklagiller, tahıllardan sonra en önemli yeri tutmaktadır. Yemeklik tane baklagil cinslerinin içerisinde yaklaşık 388 bin ha ekim alanı ile nohut ilk sırayı almakta, nohudu 223 bin ha ile mercimek, 91 bin ha ile fasulye, 3.2 bin ha ile bakla, 1.9 bin ha börülce ve 1.1 bin ha ile bezelye takip etmektedir (Çizelge 5).

Ülkemizde en fazla ekilen yemeklik baklagiller sırasıyla nohut, mercimek, fasulye, bakla, börülce ve bezelye olurken, en fazla üretilenler ise nohut, mercimek, fasulye, bakla, bezelye ve börülce olmuştur (Çizelge 6). Türkiye de yemeklik tane baklagil ekiliş, üretim ve verim değerlerinde yıllar itibariyle sürekli azalış görülmektedir. Bunun en önemli nedeni, 1990 sonrası TMO'nun baklagil alımlarını azaltması 1994'de tamamen durdurmasıyla, ürettiği ürünü elinde kalan üretici baklagil ekim alanlarını, fiyat garantisi olan ve üretimi daha kolay olan diğer ürünlere kaydırmıştır (Akova 2009). 
Çizelge 6. Yıllar itibariyle Türkiye'nin yemeklik baklagiller ekim alanı, üretim ve verim değerleri Table 6. Long term cultivation area, production and yield of grain legumes in Turkey

\begin{tabular}{l|lllllll}
\hline & YIl & Fasulye & Bakla & Nohut & Börülce & Mercimek & Bezelye \\
\hline & 1991 & 1780000 & 380000 & 8780000 & 20500 & 7900000 & 17000 \\
Ekim & 1996 & 1725000 & 245000 & 7800000 & 28500 & 6200000 & 16500 \\
Alanı & 2001 & 1750000 & 190000 & 6450000 & 29000 & 4700000 & 12500 \\
(ha) & 2006 & 1290515 & 54475 & 5243672 & 29254 & 4241700 & 15658 \\
& 2011 & 946254 & 37816 & 4464129 & 20323 & 2148473 & 13048 \\
& 2014 & 911103 & 32274 & 3885175 & 19408 & 2494937 & 11490 \\
\hline \multirow{4}{*}{ Uretim } & 1991 & 214000 & 70000 & 855000 & 2200 & 640000 & 4400 \\
(ton) & 1996 & 230000 & 46300 & 732000 & 2700 & 645000 & 4000 \\
& 2001 & 225000 & 35000 & 535000 & 2000 & 520000 & 2700 \\
& 2006 & 195970 & 10897 & 551746 & 2937 & 622624 & 4373 \\
& 2011 & 200673 & 7963 & 487477 & 2149 & 405952 & 3628 \\
& 2014 & 215000 & 6971 & 450000 & 2006 & 345000 & 2987 \\
\hline \multirow{5}{*}{ (kg/da) } & 1991 & 120 & 184 & 98 & 107 & 80 & 259 \\
& 1996 & 134 & 189 & 94 & 95 & 98 & 242 \\
& 2001 & 129 & 184 & 84 & 69 & 100 & 217 \\
& 2006 & 152 & 200 & 106 & 101 & 123 & 279 \\
& 2011 & 212 & 211 & 122 & 106 & 157 & 278 \\
\hline
\end{tabular}

(Kaynak: FAO 2015), (Source: FAO, 2015)

Ülkemizde yemeklik baklagil ekim ve üretimi bakımından Güneydoğu Anadolu, İç Anadolu ve Akdeniz Bölgeleri ön plana çıkmaktadır. Genel olarak, kırmızı mercimek Güneydoğu'da, yeşil mercimek, nohut ve fasulye İç Anadolu, bakla Ege ve Marmara'da, bezelye ise Ege, Marmara ve İç Anadolu Bölgelerinde en fazla yetiştirilmektedir (Çizelge 7).

Dünya'da ve Türkiye'de Yemeklik Tane Baklagil Dış Alım ve Satım Değerleri

Dünyada en fazla ithal ve ihraç edilen ürün bezelyedir, bunu sırasıyla fasulye, mercimek, nohut, bakla takip etmektedir. Dünya baklagil üretiminin $\% 80-85$ 'i üretilen ülkeler tarafından tüketilmekte, \%10- $5^{\prime}$ lik kısım ise uluslararası ticarete sunulmaktadır. Dünyada baklagil dışsatımı bakımından son yıllardaki en önemli ülke Kanada'dır. Kanada 1990'ı yıllardan sonra baklagil üretimini önemli ölçüde arttırmış ve son yıllarda dışsatımda aldığı pay \%25'in üzerine çıkmıştır. Kanada'yı sırasıyla ABD, Çin Halk Cumhuriyeti, Avustralya ve Türkiye takip etmektedir.

Özellikle 1980 yılından itibaren üretimde görülen artışlarla birlikte Türkiye'de tane baklagil dışsatımında önemli ölçüde artışlar gerçekleşmiş, 1990 yılında ülkemiz dünyanın en büyük dışsatımcısı olmuştur (Akova 2009). Dünyanın en büyük yeşil mercimek dışsatımcı konumunda olan ülkemizin; yeşil mercimek üretimini arttıramaması ürünün ihraç değerini önemli ölçüde düşüren mercimek tohum böcekleri ile etkili bir mücadele gerçekleştirememesi, pazarlama aşamasında modern depolama metotlarının uygulanamayışı, birim alandan alınan verimin arttırılamaması ve dolayısıyla maliyetin düşürülememesidir. Bunun sonucunda da Kanada'nın olumlu politikaları ile üretimini artırması dünya piyasalarındaki üstünlüğümüz Kanada'ya geçmiştir (Adak ve ark. 2010).

Türkiye özellikle 1997 yılından itibaren önemli miktarlarda baklagil dışalımı yapmıştır. 1994 yılına kadar dışalımın yaklaşık tamamını kuru fasulye oluştururken, bu yıldan itibaren yeşil mercimek, 1997 yılından sonra da nohut ve kırmızı mercimek dışalımımız önemli ölçüde artmıştır. Uzun yıllar baklagil ihracatçısı olarak bilinen Türkiye'nin son yıllarda ithalatında da artışlar görülmektedir. Özellikle geçmişte yok denecek kadar az olan k.mercimek ithalatı, 2008 yılında 168 bin ton ile dünyada ithalatında ilk sıraya çıkmıştır. K.mercimek ithalatı Güneydoğu Anadolu Bölgesinde yaşanan kuraklığın etkisi sonucu 2008 yılında artmış, ithalat 2012, 2013 yıllarında da devam etmiştir (Akova 2009).

\section{Yemeklik Tane Baklagil Sorunları ve Çözüm Önerileri:}

Yemeklik baklagil yetiştiriciliğinde en önemli sorun üretim maliyetlerinin yüksekliğidir. Üretimde kullanılan girdilerdeki fiyat yüksekliği maliyetleri artırmaktadır. Dünya'da ve Türkiye'de nohut ekim alanlarını sınırlayan en önemli faktör antraknoz (Ascochyta blight) hastalığıdır. Verimliliğin artırılması için, miras hukuku ile arazi parçalanması önlenerek, 
Çizelge 7. Türkiye'de bölgeler itibariyle yemeklik tane baklagil ekim alanı, üretim ve verim Table 7. Cultivation area, production and yield of grain legumes in Turkey by regions

\begin{tabular}{|c|c|c|c|c|}
\hline Bölgeler & Ürün adı & Ekilen alan (dekar) & Üretim (ton) & Verim (kg/da) \\
\hline \multirow{4}{*}{ Doğu Anadolu Bölgesi } & Fasulye & 127789 & 19064 & 158 \\
\hline & Nohut & 62998 & 7115 & 122 \\
\hline & Mercimek & 20806 & 2629 & 121 \\
\hline & Toplam & 211593 & 28808 & - \\
\hline \multirow{6}{*}{ İç Anadolu Bölgesi } & Nohut & 1369957 & 154958 & 114 \\
\hline & Fasulye & 476905 & 148302 & 302 \\
\hline & Mercimek & 18360 & 2903 & 146 \\
\hline & Bezelye & 2550 & 832 & 326 \\
\hline & Bakla & 60 & 9 & 150 \\
\hline & Toplam & 1867832 & 307004 & - \\
\hline \multirow{5}{*}{$\begin{array}{l}\text { Güneydoğu Anadolu } \\
\text { Bölgesi }\end{array}$} & Mercimek & 2252066 & 315466 & 144 \\
\hline & Nohut & 369390 & 49810 & 135 \\
\hline & Fasulye & 3774 & 916 & 243 \\
\hline & Bezelye & 601 & 30 & 50 \\
\hline & Toplam & 2625831 & 366222 & - \\
\hline \multirow{7}{*}{ Marmara Bölgesi } & Nohut & 240753 & 31587 & 137 \\
\hline & Fasulye & 62324 & 11901 & 183 \\
\hline & Bakla & 16173 & 3804 & 242 \\
\hline & Bezelye & 3010 & 736 & 235 \\
\hline & Börülce & 620 & 86 & 139 \\
\hline & Mercimek & 445 & 51 & 115 \\
\hline & Toplam & 322592 & 48048 & - \\
\hline \multirow{7}{*}{ Ege Bölgesi } & Nohut & 733730 & 73530 & 100 \\
\hline & Fasulye & 53855 & 8129 & 151 \\
\hline & Mercimek & 23550 & 2313 & 98 \\
\hline & Börülce & 17238 & 1776 & 103 \\
\hline & Bakla & 10512 & 2000 & 190 \\
\hline & Bezelye & 3816 & 1108 & 290 \\
\hline & Toplam & 842701 & 88856 & - \\
\hline \multirow{7}{*}{ Akdeniz Bölgesi } & Nohut & 921417 & 112880 & 123 \\
\hline & Fasulye & 80582 & 13639 & 169 \\
\hline & Mercimek & 9196 & 1633 & 178 \\
\hline & Bakla & 2462 & 723 & 294 \\
\hline & Börülce & 1550 & 144 & 93 \\
\hline & Bezelye & 866 & 177 & 204 \\
\hline & Toplam & 1016073 & 129196 & - \\
\hline \multirow{6}{*}{ Karadeniz Bölgesi } & Nohut & 186930 & 1160 & 148 \\
\hline & Fasulye & 105874 & 13049 & 128 \\
\hline & Bakla & 3067 & 435 & 142 \\
\hline & Bezelye & 647 & 104 & 145 \\
\hline & Mercimek & 38 & 5 & 132 \\
\hline & Toplam & 296556 & 14753 & - \\
\hline
\end{tabular}

(Kaynak: TÜIK 2014), (Source: TÜIK 2014)

Çizelge 8. Dünya'da yemeklik tane baklagillerin ithalat ve ihracat değerleri Table 8. Amounts of grain legumes imported and exported

\begin{tabular}{llllll}
\hline Ürünler & Fasulye & Bakla & Nohut & Mercimek & Bezelye \\
\hline İthalat & 3321726 & 587712 & 1114171 & 1918223 & 4316719 \\
İhracat & 3393895 & 799277 & 1158957 & 1963981 & 4820937 \\
\hline
\end{tabular}

(Kaynak: FAO 2011), (Source: FAO 2011)

ülkemizde genel olarak küçük aile işletmelerinde geçimlik tarım olarak gerçekleştirilen baklagil üretiminin pazara yönelik olarak yapılması sağlanmalıdır. Birçok tarımsal üründe olduğu gibi baklagillerde de, etkin bir pazarlama ağı olmadığı gibi örgütlenme de yetersizdir. 1990 sonrası
TMO'nun baklagil alımlarını azaltması 1994'de tamamen durdurması ve yerine herhangi bir baklagil pazarlama politikası oluşturulamaması ile birlikte üretici pazarlama sorunu yaşamaya başlamıştır. Ürettiği ürünü elinde kalan üretici baklagil ekim alanlarını, fiyat garantisi olan ve üretimi daha kolay olan diğer ürünlere 
Çizelge 9. 2012/2013 yılı Türkiye'de yemeklik tane baklagillerin ithalat ve ihracat değerleri Table 9. Import and export values of grain legumes in Turkey (2012/2013)

\begin{tabular}{llllllll}
\hline & $\begin{array}{l}\text { Üretim } \\
\text { (Ton) }\end{array}$ & $\begin{array}{l}\text { Yurt içi } \\
\text { kullanımı } \\
\text { (Ton) }\end{array}$ & $\begin{array}{l}\text { Tohumluk } \\
\text { kullanımı } \\
\text { (Ton) }\end{array}$ & $\begin{array}{l}\text { İthalat } \\
\text { (Ton) }\end{array}$ & $\begin{array}{l}\text { İhracat } \\
\text { (Ton) })\end{array}$ & $\begin{array}{l}\text { Kişi başına } \\
\text { tüketim } \\
(\mathrm{kg})\end{array}$ & $\begin{array}{l}\text { Yeterlilik } \\
\text { derecesi } \\
(\%)\end{array}$ \\
\hline Bakla & 40471 & 39688 & - & - & 216 & 0.47 & 100.54 \\
Bezelye & 101959 & 98975 & - & 946 & 2401 & 1.18 & 101.47 \\
K.Mercimek & 410000 & 326244 & 17183 & 104994 & 178090 & 3.98 & 122.41 \\
Y.Mercimek & 28000 & 50299 & 1815 & 24349 & 1322 & 0.62 & 54.22 \\
Fasulye & 200000 & 237817 & 9317 & 41408 & 1391 & 2.94 & 83.17 \\
Nohut & 518000 & 514077 & 49949 & 39442 & 36631 & 5.97 & 99.45 \\
\hline
\end{tabular}

(Kaynak: TÜIK, 2012/2013), (Source: TÜIK, 2012/2013)

kaydırmıştır. Baklagillerde ürünü ve üreticiyi garanti altına alan ürün satış kooperatifi yoktur. İç piyasa fiyatlarını etkileyen bir diğer unsur ise düşük fiyatlı gerçekleştirilen ithalattır (Akova, 2009; Çiftçi, 2004).

\section{Sonuç}

Ülkemizde toplam 24.3 milyon hektar olan tarım alanının, 735 bin hektarında yemeklik baklagil ekilmekte, yaklaşık 1 milyon ton üretim yapılmaktadır. Ülkemizde en fazla ekilen yemeklik baklagiller sırasıyla nohut (388 bin ha), mercimek (323 bin ha), fasulye (91 bin ha), bakla (3.2 bin ha), börülce (1.9 bin ha) ve bezelye (1.1 bin ha) olurken, en fazla üretilenler ise nohut (411 bin ton), mercimek (540 bin ton), fasulye (215 bin ton), bakla (7 bin ton), bezelye (2.9 bin ton) ve börülce (2.4 bin ton) olmuştur. Baklagil üretimimiz beklenenden daha düşüktür. Ülkemizde Baklagil üretiminin artırılması için:

> Girdi fiyatları düşürülmeli,

> Hastalık ve zararlılara dayanıklı, yüksek verimli çeşitler ıslah edilmeli,

> Sertifikalı tohum kullanımının yaygınlaşması için tohum desteği verilmeli,

$>$ Arazi toplulaştırma işlemleri hızlandırılıp, küçük aile işletmelerinde geçimlik tarım olarak gerçekleştirilen baklagil üretiminin pazara yönelik olarak yapılması sağlanmalı,

> Üretici birlikleri kurulmalı ve kurulması devlet tarafından desteklenmeli,

$>$ Üreticinin ürün hasadı döneminde baklagil ithalatı kesinlikle önlenmeli,

$>$ Nadas alanlarında yemeklik baklagiller ekim nöbetine sokulmalıdır.

\section{Kaynaklar}

Adak M.S., Güler M. ve Kayan N., 2010. Yemeklik Baklagillerin Üretimini Artırma Olanakları, Ziraat Mühendisliği VII. Teknik Kongresi, Ankara

Akçin A., 1988. Yemeklik Tane Baklagiller, S. Ü. Yayınları:43, Ziraat Fakültesi Yayınları, 8.377 Konya

Akova Y., 2009. IGEME Bakliyat Raporu. T.C. Başbakanlık Dış Ticaret Müsteşarlığı İhracatı Geliştirme Etüd Merkezi, Ankara

Anonim., 2014. TÜİK, Bitkisel Üretim İstatistikleri. http://tuikapp.tuik.gov.tr/bitkiselapp/bitkisel.zul . (25.02.2015)

Çiftçi C.Y., 2004. Dünyada ve Türkiye'de Yemeklik Tane Baklagiller Tarımı. TMMOB Ziraat Mühendisleri Odası Teknik Yayınları Dizisi, No.5, Ankara, 88s

FAO, 2013.2 Faostat-Agriculture http://faostat.fao.org/site/567/default.aspx\#an cor (24.02.2015)

Kün E., Çiftçi G.Y., Birsin M., Ülger A.C., Karahan S., Zencici N., Öktem A., Güler M., Yılmaz N. ve Atak M., 2005. Tahıl Ve Yemeklik Dane Baklagil Üretimi: Yemeklik Dane Baklagiller. Türkiye Ziraat Mühendisliği V. Teknik Kongresi, 3-7 Ocak 2005, Ankara, S: 396-407

Şehirali S., Gençtan T., Avcı M., Zencirci N. ve Uçkesen B., 2005. Türkiye Tahıl ve Yemeklik Tane Baklagil Üretiminin Bugünkü ve Gelecekteki Boyutlar, Türkiye Ziraat Mühendisliği V. Teknik Kongresi, s: 431-352

Şehirali S., 1988. Yemeklik Dane Baklagiller, A.Ü. Ziraat Fakültesi Yayınları, 1089, Ders Kitabı 314 